or, say, fifteen times the length of Oxford Street. Incidentally, it may be noted that twenty-two Continental countries-another record-have given special travel concessions this year to encourage attendance at the Fair by their trades buyers. In these days of quotas and other forms of restrictions on international trade, it is very significant that twenty-two Continental countries should so appreciate the international importance of the British Industries Fair.

\section{Sale of Contraceptives}

ON February 13, Lord Dawson of Penn moved the second reading of the Contraceptives Bill. The provisions of the Bill were dealt with in a leading article in Nature of February 10, p. 192. Lord Dawson said that birth control is now "part and parcel of our social fabric" and that he wished to identify himself with the view that the way to keep the sale and use of contraceptives on sound lines is "to remove the veil of doubt as to the honesty of contraception". Birth control is already accepted in practice, and if there were only wider acceptance of it in theory, the sale of contraceptives would go into normal channels. Meanwhile, he is of opinion that children and young persons require a certain amount of protection such as the bill would afford. Lord Dawson said that he is quite prepared to accept amendments provided that the principle of the bill is not undermined. The Bishop of London, while not agreeing with Lord Dawson, said he would support the Bill enthusiastically, giving as his reason the moral effect of the indiscriminate advertisement and sale of contraceptives. The Archbishop of Canterbury supported the Bill as being a serious attempt to check in some measure the growth of an evil which is poisoning the moral health, self-control and self-respect of the community. The motion for the rejection was negatived by 45 votes to 6 .

\section{Tree-Kangaroos}

The birth of a tree-kangaroo at the Gardens of the Zoological Society of London is an event well worth recording. Another was born at about this time last year. One would have supposed that the drastic change from the tropical forests of New Guinea and North Australia to a relatively small cage in London would have inhibited the reproductive activities. Even without this added interest, the presence of this strange creature in the Gardens is something more than welcome to all who are concerned with the problems presented by anomalous changes of habit and habitat in the animal kingdom. The typical kangaroo is, in itself, a sufficiently remarkable animal. For here we seem to have a convincing example of 'neo-Lamarckian' changes of form. Though how the initial stage of the leaping habit began we are scarcely likely to discover. It is not merely that the hind-legs and tail have grown inordinately large, but we have also to take into account the quite unusual nature of the reduction of the toes; for instead of disappearing on each side of a median axis, the reduction of the second and third toes has taken place on the inner side of the foot, where the claws only are visible in the living animal.

IT seems clear that the tree-kangaroo must have taken to an arboreal life after this specialisation for terrestrial leaping had taken place; though it is to be noted that, as in the wallabys, the hind-legs are shorter, and the fore-legs relatively larger than in the large ground-dwellers of the tribe. Unfortunately, the opportunity of witnessing the actual birth of any of these animals occurs only on the rarest occasions, and it would seem that even then it is by no means easy to interpret what is seen. It used to be believed that the mother seized the infant at the moment of birth in her lips, and immediately transferred it to the teat in her pouch, to which it attached itself forthwith, and retained its hold continuously for some weeks while its further development took place. For the young, in the kangaroos, are, so to speak, prematurely born, with the limbs only slightly developed. A later account gives a very different version, embracing an astonishing degree of activity on the part of this almost embryonic little body. For it is said to make its way up the fur of the parent and into the pouch, and to find the teat unaided; a course of behaviour one would have deemed im. possible.

\section{Emigration Schemes in Australia}

IN an article in NaturE of November 4 on popula. tion problems, reference was made to the failure of emigration for the time being. Commenting on the position, so far as Australia is ooncerned, Sir James Barrett, of Melbourne, in a letter to the Editor, states that the failure is not so disastrous in Australia as appears on the surface; despite the fact that, in Victoria alone, many millions of pounds will be lost on land settlement schemes. Few poople realise that industrial farming requires for success scientifie knowledge and training at least equal to that required in any learned profession. In his paper read before the World Population Conference in 1931 the late Prof. J. W. Gregory showed the importance of immigration to Australia in order that a population capable of making the utmost use of railways, etc., should be established in that country as quickly as possible. In Victoria more than $£ 10,000,000$ has been spent on irrigation works which, together with railways, were planned in accordance with a far-seeing land settlement policy. In addition, therefore, to the actual cost of land settlement schemes which the taxpayer, as Sir James Barrett says, is now forced to moet, there is this further heavy expenditure, much of which has been incurred directly for immigxation and land settlement. Prof. Gregory also made some interesting references to the varying estimates that have from time to time been drawn up as to Australia's capacity for supporting a large population. These range very widely, from about $200,000,000$ estimated by Admiral Sir Edmond Slade to about 10,000,000 and other similar low estimates made in Australia itself, for example, by F. C. Benham of the University of Sydney. Prof. Gregory's own estimate was more nearly $100,000,000$. 